\title{
The question of the use of force in Spanish practice (2012-2015): a legal perspective
}

\author{
José MARTÍN Y PÉREZ DE NANCLARES*
}

\section{INTRODUCTION}

The matters of international law that a legal adviser of a foreign ministry must tackle are many and varied. In addition to the basic function of assessing treaties and other international agreements, ${ }^{1}$ the International Legal Office (Asesoría Jurídica Internacional, AJI) of the Spanish Foreign Ministry never lacks for matters concerning the law of the sea, whether in relation to its role as an agent before the International Tribunal in Hamburg, ${ }^{2}$ as a result of an incident involving a fishing vessel flying the Spanish flag, ${ }^{3}$ as a result of an incident involving the vessels of third-party states in Spanish waters, ${ }^{4}$ or even within the context of negotiations for the delimitation of maritime boundaries. ${ }^{5}$ Nor does it want for cases involving diplomatic and consular matters ${ }^{6}$ or related to the sprawling field of

Professor of Public International Law at the University of Salamanca. Head of the International Legal Office, Spanish Foreign Ministry. The legal opinions and positions expressed in this paper are strictly the author's own and are in no way binding on the Ministry for which he currently works.

I On the role of the AJI, see the author's paper "La labor de asesoramiento jurídico internacional al Gobierno: el papel de la AJI”, in J. Martín y Pérez de Nanclares (ed.), España y la práctica del Derecho Internacional (Escuela Diplomática, Madrid, 20I4) II-52.

2 The author, for instance, appeared as agent of Spain in Case No. 2I of the International Tribunal for the Law of the Sea. The case involved a request for an advisory opinion submitted by the Sub-Regional Fisheries Commission (SRFC) in relation to the liability of the flag state for illegal fishing activities conducted within the exclusive economic zones of thirdparty states, which was delivered on 2 April 2015. Likewise, the previous head of the AJI appeared as agent of Spain in Case No. 18, M.V. "Louisa" (Saint Vincent and the Grenadines v. Kingdom of Spain), which was decided by the judgment of 28 May 2013 .

3 Such incidents can be of very different kinds. The most serious are inarguably those involving the arrest of vessels for alleged illegal fishing in the exclusive economic zone of a third-party state. The most serious such incident in the last four years was probably that involving the fishing vessel Piscator. In that case, the Spanish vessel was seized on I July 2013 by Argentina's coast guard, when, after carrying out fishing activities in the waters of the Falkland Islands, it was 8 miles outside the boundary delimiting Argentina's exclusive economic zone. The vessel was released 23 days later, after payment of an 800,000 euro fine and repurchase of the confiscated cargo of fish.

4 Aside from the long-standing question of the status of Gibraltar's waters and the related legal issues, special attention might be drawn to the incident involving the Dutch-flagged Greenpeace vessel Arctic Sunrise on I4 November 2014. In that case, the Arctic Sunrise, in breach of a Spanish Directorate General of the Merchant Marine resolution prohibiting navigation in order to facilitate an exploratory survey of the Sandia IX well to be conducted for the Spanish oil company Repsol by the drillship Rowan Renaissance, entered the exclusion zone and attempted to board the other vessel, resulting in the injury of an Italian national. The incident led to an exchange of notes verbales with the Netherlands and Italy.

It should be recalled that a number of Spanish maritime areas are still pending delimitation. On this subject, the valuable work of the former head of the AJI, J. M. Lacleta Muñoz, "Las fronteras de España en el mar" (Documento de trabajo 34/2004, Real Instituto Elcano, Madrid, 2004) remains an indispensable resource.

6 In this context, it is worth noting the case of a Spanish diplomat stationed in Brazil who killed his wife (a Brazilian national), in relation to which Spain decided to waive its agent's immunity from jurisdiction, albeit maintaining his 
sovereign immunity, whether of third states and international organizations ${ }^{7}$ or of the Spanish state itself from third parties. ${ }^{8}$ Even the foreign activities of the Spanish Autonomous Communities, as provided for under Article I49.I.3 of the Spanish Constitution and their respective statutes of autonomy, demand a good deal of the AJI's attention. ${ }^{9}$ And, of course, in the current parliamentary term, the technical work required to prepare legislative proposals that would allow the country to update its legal framework does, too. ${ }^{10}$ However, there is one especially sensitive area that stands out from all the rest.

Indeed, the issue of the prohibition of the use of force in international law and, in particular, of its exceptions has always been an extremely delicate one. This is true not only with regard to doctrine, which has obviously always been quite sensitive to how the different governments have interpreted it, ${ }^{\text {II }}$ but also, naturally, from a practical perspective, for governments' international legal advisers, amongst which the AJI is, of course, no exception. On the contrary, as the preceding contributions to this yearbook clearly show, an AJI head who has not had to struggle at some point during his or her term with a matter of this kind is a rare specimen indeed. And it is no secret that when a foreign minister asks the head of the AJI for a report on this subject, the latter is all too aware that he or she is up against an especially difficult matter of legal advice. It is thus quite pertinent for this issue of the Spanish Yearbook of International Law to include a series of short contributions showcasing how the law on the use of force has evolved from the point of view of those who have headed the AJI in recent times and had to draft reports on the matter.

immunity from execution. This case, which is currently sub judice in the Brazilian courts, was reported in the Spanish press. See, for example, El País, of 12 May 2015.

7 From amongst the many matters considered by the AJI in this area, perhaps the most highly reported in the press was that which took place on 3 July 20I3, involving the Bolivian presidential plane when the president of that country was returning to La Paz from Moscow and suspicions arose that Edward Snowden might be on board. Spain authorized the aircraft both to overfly its air space and make a refuelling stop in the Canary Islands. However, although they have received far less attention in the media, it is the aftershocks of the Babé affair that have posed the most serious legal problems. This issue has been addressed by P. Andrés Sáenz de Santa María in "Las inmunidades de las organizaciones internacionales: perspectiva general y española", in J. Martín y Pérez de Nanclares (ed.), La Ley Orgánica 16/20I5 sobre privilegios e Inmunidades: gestación y contenido (Escuela Diplomática, Madrid, in press), especially section II.3 and n. 96; it was also addressed, in the same volume, by D. González Herrera, in "Breves reflexiones en torno a las inmunidades de las organizaciones internacionales", especially n. 36 .

8 To cite just one example, it is worth noting the recent case of the Spanish galleon San José, discovered off the coast of Cartagena, Columbia, which Spain claims is the wreck of a state-owned ship and is therefore protected by sovereign immunity.

9 Needless to say, aside from the routine work in this area, in recent years the separatists challenge posed by one of the Spanish autonomous regions has created additional work for the AJI. The Spanish foreign minister himself offers a good account of the importance of this issue in his recently published collection of letters (Todos los cielos conducen a España, Planeta, Madrid, 2015), two of which were signed by the author of this paper, including one concerning precisely this issue.

10 In fact, it participated quite actively in the preparation of the drafts of Law 25/2014, of 27 November, on Treaties and Other International Agreements (Official State Gazette (BOE) no. 288, 28 November 2014), as well as the more recent Organic Law 16/2015, of 27 October, on Privileges and Immunities of Foreign States, International Organizations Headquartered or with Offices in Spain, and International Conferences and Meetings Held in Spain (BOE no. 258, 28 October 2015).

II Amongst the abundant literature on this issue, special attention might be called to the recent collective volume by M. Weller, J. W. Rylatt and A. Solomou (eds.), The Oxford Handbook of the Use of Force in International Law (Oxford University Press, Oxford, 2015). 
That said, it should be noted from the start that the distinguishing factor in matters involving the use of force in recent years has surely been the problems posed to classical categories of international law in this area by the phenomenon of terrorism. In this regard, it is worth recalling that, since 200I, a clear obligation has been taking shape in the international community to fight international terrorism in the terms established by the United Nations, ${ }^{\mathrm{I} 2}$ which, together with the increasingly blurry boundary in the case of Daesh between non-state actors (terrorist organizations) and states, is throwing traditional categories regarding the use of force into disarray. In one way or another, this comes through in many of the operations in which Spain has participated in recent years, and it must necessarily be a core focus of current international legal analysis. Other issues of equal interest, however, such as the challenge posed to Europe by human trafficking in the Mediterranean, fall beyond the scope of this paper. ${ }^{13}$

In any case, in the parliamentary term just ended (2012-2015), no decisions were taken on matters involving the use of force that were particularly controversial in terms of doctrine or how they were treated in the media. Nevertheless, the AJI was asked to issue an opinion on the matter on several occasions. Without prejudice to the necessarily confidential nature of the legal reports concerned, for the legal analysis of these opinions, this paper will begin by offering an overview of the longconsolidated (and well-known) framework established by the UN Charter, in which context Spain's participation in specific operations entailing the use of force during the stated period must be situated. Additionally, whilst this paper was being completed, a new scenario arose as a result of the grave attacks in Paris of I3 November 2015, calling for the discussion, albeit in broad terms only, of a new question the ultimate scope of which cannot yet be fully understood. The paper will conclude with a few final considerations of an evaluative nature.

I2 In this regard, and solely by way of example, of particular note is the general obligation, decided by the Security Council acting under Chapter VII of the UN Charter, to take "the necessary steps to prevent the commission of terrorist acts", especially preventing "the financing of terrorist acts" (by freezing funds), as well as for all states to cooperate through the pertinent agreements "to prevent and suppress terrorist attacks and take action against perpetrators of such acts" (SC Res. 1373 (200I) 28 September 200I). Thereafter, a long list of legal acts were adopted within the framework of both the United Nations and the European Union in relation to the international fight against terrorism. It is likewise well-known that some of the sanctions adopted within the context of the United Nations have been the subject of intense controversy within the framework of the Court of Justice of the European Union, the Kadi case being the best example. See, for example, A. Garrido Muñoz, Garantías judiciales y sanciones antiterroristas del Consejo de Seguridad de Naciones Unidas: de la técnica jurídica a los valores (Tirant lo Blanch, Valencia, 2013).

13 It is worth recalling that, in October 2015, the Security Council adopted Resolution 2240 (2015) for the purpose of helping to save the lives of migrants and victims of human trafficking by organized criminal enterprises operating on the high seas off the coast of Libya. Thus, the Security Council authorized states to inspect, on the high seas off the coast of Libya, any vessels that they have grounds to believe might be being used for migrant smuggling or human trafficking. The negotiation of this resolution was particularly problematic, as the initial draft went so far as to authorize the destruction of vessels located in Libyan ports if there were grounds to believe that they were being used for human trafficking. In the author's view, the actions authorized under the resolution could already largely have been carried out under existing international law. See n. 34 below. 


\section{THEORETICAL OVERVIEW OF THE}

\section{INTERNATIONAL LEGAL FRAMEWORK FOR THE USE OF FORCE}

Article 2.4 of the UN Charter specifically provides that "All Members shall refrain in their international relations from the threat or use of force against the territorial integrity or political independence of any state, or in any other manner inconsistent with the Purposes of the United Nations." The scope, content and nature of this structural principle of international law is specified in GA Resolution 2625 (XXV), which states that "Such a threat or use of force constitutes a violation of international law and the Charter of the United Nations and shall never be employed as a means of settling international issues." ${ }^{14}$ Likewise, the International Court of Justice (ICJ) has, since 1986, considered this prohibition to be a fundamental principle of the contemporary international order, the nature of which is at once conventional (UN Charter) and customary (custom of general international law). ${ }^{\text {Is }}$ In short, it is a norm of jus cogens.

However, there are potential exceptions to the prohibition of the use of force. Thus, both the UN Charter and ICJ jurisprudence consider the use of force to be lawful when it is carried out by means of the adoption by the Security Council of military enforcement measures under Chapter VII of the Charter (Article 42 of the UN Charter) or in case of legitimate self-defence (Article 5I of the UN Charter $).{ }^{16}$

As regards the first of these possible exceptions, the Security Council has been given the primary responsibility to authorize the use of force in international relations. In fact, since the United Nations was founded, the Security Council has authorized various international military interventions in which many different states have participated. ${ }^{77}$ However, in international practice, there have also been cases in which international military interventions were conducted without the corresponding prior authorization of the Security Council. ${ }^{18}$

With regard to the second exception, Article 5I of the UN Charter expressly recognizes "the inherent right of individual or collective self-defence if an armed attack occurs against a Member of the United Nations, until the Security Council has taken measures necessary to maintain

I4 GA Res. 2625 (XXV), 24 October 1970.

is Military and Paramilitary Activities in and against Nicaragua (Nicaragua v. United States of America), Judgment of 27 June 1986, ICJ Reports (1986), I87 to 190.

${ }_{16}$ Legality of the Threat or Use of Nuclear Weapons, Advisory Opinion of 8 July 1996, ICJ Reports (I996), 38.

${ }_{17}$ In some cases, states have participated individually as part of a coalition, as with the first intervention in Iraq (SC Res. 678 (1990) 29 November 1990; SC Res. 686 (1991) 2 March 199I; and SC Res. 687 (199I) 3 April 1991). In others, they have done so through an international military organization, as in the intervention in Libya (SC Res. I973 (201I) I7 March 20II).

18 Aside from the specific case of Korea in 1950 (SC Res. 83 (1950) 27 June 1950; GA Res. 377 (1950) 3 November 1950), the two paradigmatic cases have been the intervention in the Federal Republic of Yugoslavia (NATO air strikes beginning on 24 March 1999 without a mandate from the Security Council and based on a unilateral decision by that international organization aimed at halting the grave violations of human rights in Kosovo) and the second intervention in Iraq (the US and a group of allied states used force in Iraq even through Resolution I44I of 8 November 2002 did not grant them authorization or coverage to do so). The first of these interventions earned timid and highly qualified criticism from the Secretary-General of the UN; in contrast, he considered the second to be an attack constituting an illegal invasion. For a Spanish perspective, see P. Andrés Sáenz de Santa María, "Kosovo: todo por el Derecho Internacional pero sin el Derecho Internacional”, 28 Meridiano CERI (1999) 4-8. 
international peace and security." However, this exception must be strictly construed and, in the opinion of the ICJ, "would warrant only measures which are proportional to the armed attack and necessary to respond to it" ${ }^{19}$ Moreover, from a substantive point of view, along with the requirements of necessity, imminence and proportionality of the armed response, it is necessary to show the existence of an "armed attack which has already occurred". ${ }^{20}$ To this end, with regard to terrorism, it is increasingly important to determine whether the aforementioned "armed attack" can come from non-state actors. ${ }^{21}$ Likewise, from a formal perspective, the aforementioned Article 5I provides that these measures "shall be immediately reported to the Security Council", which shall retain the authority "to take at any time such action as it deems necessary in order to maintain or restore international peace and security".

Furthermore, there is an emerging principle of international law whereby "[e]ach individual state has the responsibility to protect its population from genocide, war crimes, ethnic cleansing and crimes against humanity." However, when the state concerned lacks the necessary capacity to fulfil this obligation throughout its territory, "[ $t$ ] he international community should, as appropriate, encourage and help States to exercise this responsibility and support the United Nations in establishing an early warning capability". ${ }^{22}$ Needless to say, this is on the understanding that the "appropriate means" in question must be of a peaceful nature, such that, were it ultimately necessary to use force, the aforementioned requirements would first have to be met. However, this responsibility to protect is still in its infancy, is still taking shape, and the scope of the possible obligations arising under it for states has not been adequately defined. ${ }^{23}$ Nevertheless, it does coincide with one of Spain's objectives ${ }^{24}$ and is undeniably linked to outstanding institutional issues, such as reforming the right of veto in the Security Council. ${ }^{25}$

is Advisory opinion, Legality of the Threat..., supra n. I6, 4I.

${ }_{20}$ Military and Paramilitary Activities..., supra n. 15, 191 and 195; Case Concerning Oil Platforms (Islamic Republic of Iran v. United States of America), Judgment of 6 November 2003, ICJ Reports (2003), 5 I.

${ }_{21}$ The question took on increasing urgency following the attacks of in September. See D. Murphy, "Terrorism and the Concept of "Armed Attack" in Article 5I of the UN Charter", 4I Harvard Journal of International Law (2002), 4I-51; and C. Greenwood, "War, Terrorism and International Law", 56 Current Legal Problems (2003), 505-530. It remains relevant today. See, for example, K. M. Trapp, “Can Non-State Actors Mount an Armed Attack?”, in M. Weller (ed.), supra n. II, at $679-696$.

${ }_{22}$ So it is defined in GA Res. 60/1, 24 October 2005, paragraph 138.

23 See in extenso the recent book by R. Thakur and W. Maley (eds.), Theorising the Responsibility to Protect, (Cambridge University Press, Cambridge, 2015). For a Spanish perspective, see, for example, C. Diaz Barrado, "Algunas reflexiones sobre la responsabilidad de proteger”, in S. Torres Bernárdez (ed.), El Derecho Internacional en el mundo multipolar del siglo XXI: Obra bomenaje al profesor Luis Ignacio Sánchez Rodríguez (Iprolex, Madrid, 2013) 739-754.

24 On 23 and 24 June 2015, the $5^{\text {th }}$ meeting of the Global Network of Responsibility to Protect $\left(\mathrm{R}_{2} \mathrm{P}\right)$ Focal Points was co-hosted in Madrid by the governments of Spain and Chile, the Global Centre for the Responsibility to Protect, and the Stanley Foundation under the title "Iо Years of the Responsibility to Protect: Responding to New Challenges and Threats to Vulnerable Communities". Spain and Chile likewise co-hosted an Arria-formula meeting of the Security Council last December, open to all UN Member States and civil society, on the principle of the responsibility to protect and non-state actors. To the author's knowledge, it was the first time the Security Council discussed this issue in relation to non-state actors.

25 In this regard, the 2013 French proposal to reform the veto system is the most interesting. See C. Gutiérrez Espada, "Responsabilidad de proteger y el derecho de veto en el Consejo de Seguridad", 3 Revista del Instituto Español de Estudios Estratégicos (2014) I-28. 
In any case, as discussed elsewhere, in the author's view we are currently at a turning point, which will most likely require "better adaptation of international structures and their institutions", as well as "greater flexibility in the legal treatment of new phenomena, such as international terrorism and organized crime, that might imperil inalienable values of democratic societies". ${ }^{26}$ However, whilst the answers to the new challenges are being sought, it is necessary to respect the rules of jus cogens and reject all temptation to embrace categories such as preventive war and similar constructions. ${ }^{27}$

Having looked at the general framework for the use of force in international law, we are now in a position to examine Spain's specific participation in military operations that have involved the use of force.

\section{THE USE OF FORCE IN LIGHT OF RECENT SPANISH PRACTICE}

(I) Spain's Participation in International Missions:

International and Domestic Legal Requirements

Spain's participation in missions involving the use of force, in addition to meeting the requirements of international law, must also fulfil those of the country's domestic law. In this regard, the Organic Law on National Defence fully reflects international law on the matter and, in establishing the conditions for participation in foreign missions in Article 19, paragraph a), stipulates, amongst other things, that the missions in question must be undertaken "by express request of the government of the state in whose territory it will take place or have been authorized by the Security Council of the United Nations". ${ }^{28}$ Additionally, the government is required to seek authorization for them from Congress (Article i7).

In this regard, in the last parliamentary term (2012-2015), Spain participated in a dozen international military operations. Four of them were simply the continuation, during the period, of previously launched operations. This group would include the intervention in Lebanon, ${ }^{29}$ the intervention in Bosnia Herzegovina, ${ }^{30}$ the fight against piracy off the coast of Somalia, and the training of Somali security forces..$^{31}$

In eight other cases, the operations were launched during the term itself. In four of these cases, the operation was carried out in the context of EU operations; this group included Spain's contribution

26 J. Martín y Pérez de Nanclares, "La sociedad internacional en la era de la mundialización: hacia un nuevo e inadecuado concepto de la legítima defensa”, in J. M. Martínez de Pisón Cavero and M. Urrea Corres (eds.), Seguridad internacional y guerra preventiva - Análisis sobre los nuevos discursos sobre la guerra (Perla ediciones, Logroño, 2008) 229-246, at 245 .

27 In the same volume cited in the preceding note, see the contributions by C. Gutiérrez Espada, "Los conceptos de 'guerra preventiva' y de 'egítima defensa preventiva' a la luz de la jurisprudencia internacional contemporánea”, 249-282, and M. Urrea Corres, "Hacia la definición de una nueva estrategia de seguridad colectiva para las Naciones Unidas", 333-363.

28 Organic Law 5/2005, I7 November 2005, on National Defence (BOE no. 276, I8 November 2005).

29 The United Nations Interim Force in Lebanon (UNIFIL) was created in 1978. Its mandate was expanded in 2006, which is when Spanish participation began under SC Res. I70I (2006) II August 2006 (and any modifications thereto). Specifically, UNIFIL is an operation in Southern Lebanon intended to prevent hostilities between Hezbollah and Israel.

30 Operation ALTHEA in Bosnia-Herzegovina. It was launched in 2004.

${ }^{3}$ Operation EUTM Somalia, an EU military mission to train the Somali security forces to fight terrorism and piracy. It was launched in 2010. 
to the military training operations in Mali ${ }^{22}$ and the Central African Republic, ${ }^{33}$ as well as the military actions undertaken in the south central Mediterranean to fight human trafficking networks, stop irregular migratory flows, and prevent more people from dying at sea. ${ }^{34}$ One of the operations, aimed at providing training for the Afghan armed forces, was undertaken within the framework of NATO.35 Finally, Spain also participated in three other operations to support France in Mali ${ }^{36}$ and the Central African Republic, ${ }^{37}$ as well as in the international coalition against Daesh (in Iraq)..$^{38}$ These are undoubtedly the most relevant operations from a legal standpoint, and they will thus be the focus of the following analysis.

(2) Spain and Collective Self-defence: The Cases of Mali and Iraq

\section{(a) Supporting the Government of Mali}

In January 2013, France undertook a military operation in Mali with the aim of stopping the offensive of terrorist groups in the north of the country. Spain participated in it. To determine whether it was consistent with international law, one must take four important factors into account.

First, Spain's actions took place within the context of an international operation led by France, in which several European states (the UK, Germany, Belgium and Denmark), non-European states (the US and Canada), and even neighbouring states (Mauritania and Algeria) participated.

Second, the military support was expressly requested by the legitimate Malian authorities in a letter sent by the country's president to his French counterpart, ${ }^{39}$ a cardinal point from the perspective of both international and domestic law.

32 Operation EUTM Mali, an EU military training mission to increase the capacities of the Malian armed forces with a view to restoring the country's territorial integrity. Resolution of the Spanish Council of Ministers of I8 January 2013 and authorization by the Spanish Congress of 30 January 2013.

33 Operation EUFOR RCA, carried out between April 2014 and March 2015; resolution of the Spanish Council of Ministers of 7 March 2014 and authorization by the Spanish Congress of 20 March 20I4. Subsequently, operation EUMAM RCA, launched in March 2015; resolution of the Spanish Council of Ministers of 17 April 2015 and authorization by the Spanish Congress of 22 April 2015.

34 Operation EUNAVFOR Med or Sophia, launched on 22 June 2015; resolution of the Spanish Council of Ministers of IO July 2015 and authorization by the Spanish Congress of 20 July 2015.

35 Operation Resolute Support. It was launched on I January 2015 with the aim of facilitating the fight against the insurgency and Afghan reconstruction. This operation was agreed by resolution of the Spanish Council of Ministers of $\mathrm{I2}$ December 2014 and was authorized by the Spanish Congress on I8 December 2014.

36 Operación Marfil (Operation Ivory) in support of the French Operation Serval (currently, Operation Barkahne) in Mali and MINUSMA. It was launched in January 2013, following the corresponding resolution of the Spanish Council of Ministers of I8 January 2013 and authorization of the Spanish Congress of 30 January 2013. Its legal basis is SC Res. 2085 (2012) 20 December 2012.

37 Operación Alfa-Charlie (Operation Alpha-Charlie) in support of the French operation in the Central African Republic and MINUSCA, especially including the provision of air support for tactical and logistical transport for international operations in the Central African Republic. It was launched on 2I March 20I4, by resolution of the Spanish

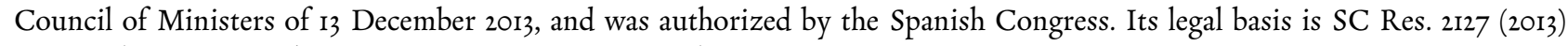
5 December 2013; see also SC Res. 2I2I (2013) Io December 2013.

$3^{8}$ It is an operation to train the Iraqi army as part of the international coalition against Daesh. It was agreed by resolution of the Spanish Council of Ministers of Io October 2014 and was subsequently authorized by the Spanish Congress on 22 October 2014 .

39 This request followed up on a previous letter sent on I8 September 2012 by the transitional authorities of Mali to the UN Secretary-General, in which they requested "authorization of deployment through a Security Council resolution, under 
Third, the military operations had sufficient legal coverage under UN Security Council resolutions issued under Chapter VII of the Charter, specifically, SC Res 2085 (2012).4

Fourth, at its I4 January 2013 meeting following the start of the operations, the Security Council itself fully endorsed the legality of the actions, ${ }^{41}$ a posture it later confirmed in subsequent resolutions, ${ }^{42}$ up to the most recent one in June $2015 .{ }^{43}$

In short, the decision taken by the Spanish government to provide support for the operation undertaken by France (and other countries) to use logistical support actions to stop the offensive of terrorist groups was fully consistent with international law.

\section{(b) Supporting the Government of Iraq}

In a very similar sense, in September 20I4, the question was posed of whether to provide military assistance to Iraq, at the express request of its legitimate government, to fight an armed or terrorist group controlling part of its territory. To this end, the Security Council adopted two important resolutions to address the advance of the so-called Islamic State in Iraq and the Levant (ISIL) in the summer of 20I4. ${ }^{44}$ Two key aspects of these resolutions should be underscored. First, they confirmed the existence of an attack on Iraq's territorial integrity, noting that "the advance of ISIL on Iraq's sovereign territory is a major threat to Iraq's future" and expressing the body's "gravest concern that territory in parts of Iraq and Syria is under the control of the Islamic State in Iraq and the Levant (ISIL)". Second, they confirmed both the commission of serious international crimes and the existence of "continued gross, systematic and widespread" violations of international law. As a result, the Security Council expressly called for international support for Iraq, although it did not expressly

Chapter VII as provided by the United Nations Charter, of an international military force to assist the Armed Forces of Mali to recover the occupied regions in the north of Mali”. Likewise, on I2 October 20I2, another letter sent to the same recipient stressed "the need to support, including through such an international military force, the national and international efforts to bring to justice the perpetrators of war crimes and crimes against humanity committed in the north of Mali".

40 SC Res. 2085 (2012) 20 December 20I2, on the situation in Mali. Acting under Chapter VII of the UN Charter, the Security Council authorized Member States and international organizations to provide training to Malian forces (paragraphs 6 to 8), the deployment of the African-led International Support Mission in Mali (AFISMA) (paragraphs 9 to I2), and Member States and international organizations "to provide coordinated support to AFISMA, including military training, provision of equipment, intelligence, logistical support and any necessary assistance in efforts to reduce the threat posed by terrorist organizations" (paragraph $\mathrm{I} 4$ ).

${ }_{4 \mathrm{I}}$ France did not request any specific authorization from the Security Council, although it considered that the requirements under Article 5I of the Charter had been met. This legal basis was not challenged by any of the other 14 members of the Security Council. In France's opinion, the letter from the president of Mali requesting its intervention in the context of self-defence provided sufficient legal grounds to defend the consistency of its intervention with international law.

42 SC Res. 2100 (2013) 25 April 2013. Under this resolution, issued under Chapter VII of the Charter, the Security Council established the United Nations Multidimensional Integrated Stabilization Mission in Mali (MINUSMA) (paragraph 7), urged Member States to continue to provide support to AFISMA until the mission was fully deployed (paragraph 10), and asked Member States and international organizations to "provide coordinated assistance, expertise and training" (paragraph 23). See also SC Res. 2164 (2014) 24 June 2014.

${ }_{43}$ SC Res. 2227 (2015) 29 June 2015. The Security Council, acting under Chapter VII of the Charter, extended the mandate of MINUSMA (paragraph I2), called on the EU to coordinate its missions (EUTM Mali) with MINUSMA (paragraph 3I), and authorized French forces to "use all necessary means (...) to intervene in support of elements of MINUSMA when under imminent and serious threat upon request of the Secretary-General” (paragraph 27).

44 SC Res. 2169 (2014) 30 July 2014; SC Res. 2170 (2014) I5 August 2014. 
authorize the use of force. ${ }^{45}$ Nevertheless, as of that moment, under international law, the necessary support could legally be provided to the government of Iraq to ensure that it fulfilled its "primary responsibility (...) to protect civilian population on [its] territories, in accordance with [its] obligations under international law" and "to combat by all means, in accordance with the Charter of the United Nations and international law, (...) threats to international peace and security caused by terrorist acts" ${ }^{46}$ In the author's view, in light of these resolutions, it was thus perfectly legal for Spain to adopt measures of support consisting, for example, in advising security forces, selling equipment provided, of course, that the equipment in question did not include weapons whose sale is prohibited under international law and that it was appropriate for the stated goal - , funding counter-terrorism measures, etc. In contrast, given this legal basis, there could be grounds for doubting whether it would be possible to include, in a broader sense, direct assistance to the Iraqi government involving the use of force.

However, in the case at hand, there may be sufficient legal arguments to hold that the ISIL attacks constituted an "armed attack" in the sense required by international law for recognition of Iraq's inherent right to self-defence as provided for under Article 5I of the UN Charter. It could thus be argued that the Iraqi government had the right to use force in self-defence to recover the Iraqi territory under the military control of ISIL and, at the same time, to effectively stop the commission of grave international crimes in its territory. As this right to self-defence can be individual (of the Iraqi government itself) or collective (with the assistance of other states), in the case of an express request for support from the Iraqi government, as long as the use of force employed was proportional and the measures taken were reported immediately to the Security Council, the Spanish decision to provide military support to the legitimate government of Iraq would be consistent with international law. This was precisely the context in which the decision expressed by Spain through its Foreign Minister at the conference in Paris on I5 September 2014 was taken.

In short, the Spanish government's decision to provide support to the Iraqi government to help it restore control over the part of its territory held by ISIL and halt the commission of crimes against humanity was, in the author's view, consistent with international law.

(3) Spain and the Use of Force in the Absence of an Express Request by the State Concerned: The Case of Syria

The difference between Iraq and Syria was precisely the absence of an express request for support by the Syrian government to take measures for the use of force of the kind the Iraqi government did request. ${ }^{47}$ True, the legal services of other states believed that, in the case of Syria, too, sufficient

45 Specifically, SC Res. 2169 (2014) emphasized "the importance of the international community supporting Iraq", whilst SC Res. 2170 (2014) called upon all states "to take all measures as may be necessary and appropriate and in accordance with their obligations under international law to counter incitement of terrorist acts motivated by extremism and intolerance".

46 SC Res. 2170 (2014), supra n. 44.

47 On the relevance of consent or armed intervention by request of the legitimate government of the state concerned, see: C. Diaz Barrado, El consentimiento, causa de exclusión de la ilicitud del uso de la fuerza, en Derecho Internacional (Universidad de Zaragoza, Zaragoza, 1989). Likewise see GA Res. 3314 (XXIX), approving the Definition of Aggression, especially Art. 3 e) of the Definition. Regarding the situation in Syria resulting from the existence of the veto in the Security 
conditions had been met to advocate the use of force in accordance with international law, especially once the use of chemical weapons against the civilian population was revealed. The question thus arises of whether an intervention can be justified on the grounds of the emerging - and already mentioned $-{ }^{4}$ principle of the responsibility to protect. ${ }^{49}$

Nevertheless, in the author's view, notwithstanding any other opinion better founded in law, there remain sufficient legal doubts regarding the full compliance with international law of measures for the use of force taken in the absence of both a resolution of the Security Council under Chapter VII of the Charter and a case of collective self-defence at the express request of the government concerned.

In any case, it is certainly true that the government in question controls only a small part of its territory. Moreover, the legal situation was undeniably further complicated by the terrorist attacks (or, perhaps, "armed attacks") committed in Paris by those fighting their respective legitimate governments in Iraq and Syria. And that aspect must be addressed separately.

(4) The Use of Force under Mutual Military Assistance Clauses: The European Response to the Paris Attacks

Indeed, this paper would not be complete without a few brief considerations on the new legal landscape created by the attacks of 13 November 2015 in Paris, in which 130 people died. In addition to non-legal considerations that are not relevant to this paper, France held that it was a case of collective self-defence and accordingly considered that the mutual assistance mechanism provided for under Article 42.7 TEU could be invoked. ${ }^{50}$ It is thus a highly relevant mechanism that calls for the examination of at least six legal aspects..$^{5 \mathrm{I}}$

First, the wording of the provision seems to make clear that ratione materiae the mechanism may only be triggered in the event of the occurrence of a prior "armed aggression" (una agresión armada", "une aggression armée", "eines bewaffneten Angriffs"). Thus, from the very start, it is necessary to determine whether the I3 November attacks can indeed be classified as an "aggression" of an "armed" nature. In the author's view, despite the obvious difficulties (and consequences) that this entails, sufficient arguments may exist to defend the existence of such a nature: the events are of such gravity that they can hardly be ascribed to a traditional act of terrorism; the acts were perpetrated with a remarkable degree of external organization; and, at least indirectly, it is not hard to show how the events fit into the greater context of an armed conflict (in Syria and Iraq). This, however, does not

Council, see also the contribution by C. Gutiérrez Espada, supra n. 25, at 3-5 ("I. El uso legal de la fuerza armada contra el régimen sirio").

48 See Section II above, in fine.

49 On indirect humanitarian intervention in fulfilment of the responsibility to protect, see the interesting paper by A. Sánchez Legido, “¿Podemos armar a los rebeldes? La legalidad internacional del envío de armas a grupos armados no estatales a la luz de los conflictos libio y sirio”, 29 Revista Electrónica de Estudios Internacionales (2015) I-34, especially at 29-33.

so Under this provision, introduced by the Treaty of Lisbon, "If a Member State is the victim of armed aggression on its territory, the other Member States shall have towards it an obligation of aid and assistance by all the means in their power, in accordance with Article 5I of the United Nations Charter. This shall not prejudice the specific character of the security and defence policy of certain Member States."

${ }_{51}$ Regardless of the precise legal interpretation of the scope of Art. 42.7 TEU, it also seems appropriate to link this mechanism with the possibility of establishing permanent structured cooperation, in the sense provided for under Art. 42.6 TEU. The current situation probably calls for establishing such cooperation without much delay. 
mean that there were not also certain singularities that cannot be ignored, such as the peculiar nature of the actors. In this regard, the organization to which the acts were attributed (Daesh) cannot, strictly speaking, be considered a state. However, it is far more than a terrorist organization and there is sufficient evidence of the armed nature of the attack, as they have sole de facto control over a considerable portion of the territory of two states (Iraq and Syria), they aspire to form their own state, and they pose a grave threat to international peace and security.

Second, the armed aggression must occur ratione loci on the territory of an EU Member State ("on its territory", "en su territorio", "sur son territoire", "auf das Hoheitsgebiet"), which, in this case, would not seem to pose any problem at all. It affected France directly and, through its organization and the subsequent flight of the perpetrators, the territory of other EU Member States as well, at least, Belgium.

Third, if it is agreed that the aforementioned conditions were met, there could be a true obligation to assist on the part of the other EU Member States. That, however, is a highly debatable (and debated) issue for which there is as yet no single answer commonly accepted by all. A grammatical interpretation of the provision would clearly seem to suggest that this obligation is indeed of an obligatory nature and not merely a reference to the possibility of providing assistance. A teleological interpretation would support that view, as, during the drafting of the provision, the wording was clearly not chosen by chance and the drafters were fully cognizant of what they were establishing. ${ }^{52}$ Even a systematic interpretation of the provision shores up this view, as Article 42.7 TEU clarifies that the Member States must moreover provide this assistance "by all the means in their power" ${ }^{53}$ In the author's view, however, we are dealing more with what the German Constitutional Court, in its judgment on the Treaty of Lisbon, has considered a political obligation ("eine politische Schuld") ${ }^{54}$ than a genuine obligation of a legal nature..$^{55}$ Needless to say, in practice the specification of what

52 CONV 46I/o2, of 16 December 2002, Final report of Working Group VIII - Defence, especially pp. 20 and 2I.

53 Some German commentators on this provision do hold this view and believe that there exists a genuine legal obligation (“eine echte Rechtspflicht”). See, for example, H.-J. Cremer, “Art. 42”, in C. Callies and M. Ruffert (eds.), EUV AEUV, Das Recht der Europäischen Union mit Europäischer Grundrecbtecharta (Beck Verlag, Munich, 201I) 415-427, at 42I422, paragraph 16; and W. Kaufmann-Bühler, “Art. 42”, in E. Grabitz, M. Hilf and M. Nettesheim (eds.), Das Recht der Europäasichen Union: EUV/AEUV (Beck Verlag, Munich, 20I5) I-38, especially at 3I-32, paragraphs 67-68 ("Beistandspflicht").

54 BVerfGE I23, 267, especially paragraphs 385-386.

55 In this regard, one school of thought has held that the value of this clause lies more in its political significance than its actual legal scope. See L. N. González Alonso, "Unidos en la diversidad: hacia una configuración flexible de la política de seguridad y defensa en la Unión Europea”, 7 Revista General de Derecho Europeo (2005), at 22. Likewise, some authors have argued that, in practice, this clause lacks its own content, as NATO Member States will turn to NATO and neutral states will base themselves on their neutral statuses when it comes to assisting by military means. See S. Dietrich, "Die rechtlichen Grundlagen der Verteidigungspolitik der Europäischen Union”, 66 Zeitschrift für ausländisches öffentliches Recht und Völkerrecht (2006) 663-697, especially at 694. It has likewise been called a "barely operational" clause the practical effect of which is simply to be applied when the victim of the attack is a neutral or non-aligned state or when the victim is an EU Member State that is also a member of NATO if the territory concerned lies outside NATO's protective umbrella; see M. Urrea Corres, "La política (común) de seguridad y defensa en el Tratado de Lisboa. La eficacia como objetivo, la flexibilidad como instrumento y la ambición como propuesta”, 33 Revista Española de Derecho Europeo (2010) 91-I20, at II4-II5. However, other authors have argued that the mechanism provided for under Art. 42.7 TEU is an "essential element" of EU security and defence policy and have recommend implementing the permanent structured cooperation provided for under Art. 42.6 
exactly "all the means" to be made available to the Member State concerned means will require prior negotiation, and it will ultimately be the state offering these means that will decide the exact nature thereof; and, of course, they need not be solely military in nature. One exception to the foregoing can be found in relation to those Member States with neutral statuses. The second sentence of the provision expressly states that the obligation does not apply to them insofar as it notes that the first sentence "shall not prejudice the specific character of the security and defence policy of certain Member States." ${ }^{6}$

Fourth, and of particular importance to the matter at hand, the TEU also provides that this obligation of aid and assistance must be fulfilled in accordance with Article $5 \mathrm{I}$ of the UN Charter. In reality, in the author's view, it is not necessary for Article 42.7 TEU to state this requirement expressis verbis, as it is implicit in the principle of the rule of law on which all of the EU's activity is founded and to which Article 2 TEU expressly refers. ${ }^{57}$

Fifth, the question arises of whether the assistance mechanism provided for under Article 42.7 TEU can be triggered independently of Article 5 of the Washington Treaty, or whether, on the contrary, it may only be invoked following prior invocation of the latter, provided the state concerned is also a NATO member and the territory in which the armed aggression took place falls within the territorial scope of the aforementioned Article $5.5^{58}$ The former interpretation is supported by the reference in the second paragraph of the provision itself clarifying that "Commitments and cooperation in this area shall be consistent with commitments under the North Atlantic Treaty Organisation, which, for those States which are members of it, remains the foundation of their collective defence and the forum of its implementation." 59 This requirement of consistency with commitments under NATO would seem to indicate that the actions undertaken must be compatible with the commitments undertaken in the context of that organization; anything else would distort the very essence of the mutual defence clause in the context of the EU. ${ }^{60}$ Nevertheless, arguments can also

TEU as soon as possible; see F. Aldecoa Luzarraga, "Una política de defensa europea compatible con la Alianza Atlántica", 177 Cuadernos de Estrategia (2015), 47-73, especially at 50.

56 This reference was introduced in Article 42.7 TEU to content the Union's neutral and non-aligned states, i.e. Austria, Cyprus, Finland, Ireland, Malta and Sweden.

57 Logically, the requirement to respect the rule of law includes the obligation to respect international law and, in particular, the essential core thereof, as enshrined in Article 5I of the UN Charter. Moreover, the very first sentence of the title regulating the Common Foreign and Security Policy in the TEU clearly states that "The Union's action on the international scene shall be guided by the principles which have inspired its creation, development and enlargement, and which it seeks to advance in the wider world", which include both the general principle of the rule of law and the more specific one of the requirement of "respect for the principles of the United Nations Charter and international law". However, given the scope of the implementation of the assistance mechanisms provided for in Art. 42.7 TEU, it is worth clarifying the specific requirement (clear in international law) that it meet the requirements of Art. $5 \mathrm{I}$ of the Charter.

${ }_{58}$ The disparate consequences of the two interpretations are clear. In the first case, the direction of the collective selfdefence action taken in response would clearly be led by the state that suffered the armed aggression (with the aid or support of the other Member States). In contrast, in the second, NATO would play a considerably more prominent role.

59 Emphasis added by the author.

60 In this regard, see, for example, D. Rubio García, "Las cláusulas de asistencia mutua y solidaridad introducidas por el Tratado de Lisboa: el refuerzo de la seguridad y la defensa en la Unión Europea", Documento de Trabajo 57/20II (Fundación Alternativas-Ministerio de Defensa, Madrid, 20II), 8I. 
be found in favour of a sort of "NATO first" principle, and so it has been argued in the literature. ${ }^{6 \mathrm{I}} \mathrm{In}$ the author's view, a sort of necessary coordination with NATO must be imposed, without interfering with the independence of the mechanism introduced in Article 42.7 TEU, with the aim of shaping a security and defence policy specific to the Union. In this regard, the participation of the EU's institutions in the mechanism provided for under Article 42.7 is extraordinarily limited, although some authors have concluded that there exists a requirement for the European Council to intervene by consensus. ${ }^{62}$

Finally, sixth, the relationship between this mechanism and the solidarity clause provided for under Article 222 TFEU must be examined. According to the first sentence of paragraph I of that provision, "The Union and its Member States shall act jointly in a spirit of solidarity if a Member State is the object of a terrorist attack or the victim of a natural or man-made disaster." The second sentence of that same paragraph goes on to clarify that, in the event of a case regulated by this provision of the TFEU, "The Union shall mobilise all the instruments at its disposal, including the military resources made available by the Member States, to (...) assist a Member State in its territory, at the request of its political authorities, in the event of a terrorist attack" ${ }^{63}$ At the same time, paragraph 2 establishes the requirement for the Member States to "coordinate between themselves in the Council". Clearly, these provisions refer to an obligation to assist and not merely the possibility of assisting ("shall assist it"), although it is left to the states themselves to specify the exact measures to be taken. ${ }^{64}$ However, this case is predicated on the occurrence of a terrorist attack, rather than an armed attack. This seems to suggest that, in the case of Article 222 TFEU, the attack must have been carried out by a non-state organization, in contrast to the case of "armed aggression" provided for under Article 42.7 TFEU, which would seem to refer more to an attack by another state. ${ }^{65}$ Moreover, the Member States are to provide their assistance in the territory of the Member State that was the object of the terrorist attack (rather than outside of it). Finally, there is a requirement for coordination in the Council, whilst the Union has the competence to implement a decision (adopted by the Council acting on a joint

${ }_{61}$ This is the interpretation offered by many of the leading German commentators on the provision. See, for example, H.-J. super n. 53, 422-423, paragraph I8; E. Regelsberger and D. Kugelmann, “Art. 42”, in R. Streinz (ed.), EUV/AEUV, $2^{\text {nd }}$ ed. (Beck Verlag, Munich, 20I2), 285-289, especially at 287-288, paragraph II. Amongst Spanish authors, see, for example, M. Urrea Corres, supra n. 55, at II4.

${ }^{62}$ See D. Rubio García supra n. 60, at 8I.

63 See Council Decision 2014/415/EU of 24 June 2014 on the arrangements for the implementation by the Union of the solidarity clause, OJ L 192, I July 2014, and the corrigenda in OJ L 221, 25 July 2014, and OJ L 275, I7 September 2014.

${ }_{4}$ Declaration No. 37 on Art. 222 TFEU, annexed to the Final Act of the Intergovernmental Conference which adopted the Treaty of Lisbon, clearly states that "none of the provisions of Article 222 is intended to affect the right of another Member State to choose the most appropriate means to comply with its own solidarity obligation towards that Member State."

65 However, as noted above, distinguishing between the cases provided for under Arts. 42.7 TEU and 222 TFEU clearly poses certain legal difficulties. Given that the former refers to Art. 5I of the UN Charter and the Security Council has considered attacks launched by certain terrorist organizations to be an "armed attack" or "armed aggression", making the distinction may not always be simple. And, of course, the case at hand may be one such occasion. In any case, it may be of some interpretive assistance that, in discussing this provision, the Convention made it clear, for instance, that the solidarity clause could not be invoked in the case of an attack by a third state, even if carried out by terrorist means, and that, therefore, such cases would need to be addressed under Art. 42.7 TEU; CONV 46I/o2, supra n. 52, at 20. The solidarity clause would operate as a kind of lex specialis. 
proposal by the Commission and the High Representative of the Union for Foreign Affairs and Security Policy). ${ }^{66}$

Therefore, in the specific case of the attacks in France of 13 November 2015, in the author's view, there may be sufficient grounds to qualify them as an "armed aggression", as provided for under Article 42.7 TEU, understood as a synonym for the requirement of an "armed attack" referred to under Article 5I of the UN Charter. Furthermore, in light of recent developments in international law, a compelling case could be made to equate Daesh (with its aspiration to become ISIS or the Islamic State, its defined population, and its de facto control of a defined territory) to the traditional perpetrator of the acts for which Article 5I of the Charter may be invoked, even though it is not, strictly speaking, a state. ${ }^{67}$

\section{FINAL CONSIDERATIONS}

The question of the use of force is one of the most controversial issues in international practice. It is probably also one of the most sensitive questions a legal adviser to a foreign ministry might have to deal with, if his or her legal interpretation differs from the policy decision taken by the government he or she serves. This matter, like few others, reveals the dialectics that can exist between a legal adviser's ineluctable ethical duty to establish the inviolable legal limits set by international law on the international action of his or her government and the possible policy decisions that government might take regarding action in this area.

This notwithstanding, in the author's view, all Spanish actions involving the use of force during the parliamentary term just ended managed to avoid that dialectics and proved to be fully consistent with international law. The author thus had the great fortune of not having been faced at any time with a contradiction between his legal opinion and the policy position of the party requesting it.

That, however, does not preclude finding, in the words of a colleague and specialist in the matter, that "the collective security system designed in the Charter is unable to provide an effective response to extreme situations in which the use of armed force emerges as a necessary resource to preserve absolutely essential interests, whether for national sovereignty or for the international community as a whole" ${ }^{68}$ The responsibility to protect and the new forms of global terrorism by actors who aspire to statehood are two good examples of the challenges currently facing international law. And also the AJI...

66 Should the decision have defence implications, the Council would act in accordance with the requirements of Art. 3I TEU, i.e., unanimously whilst allowing for the possibility of constructive abstention.

${ }_{67}$ See a more detailed analysis of these questions in M. Urrea Corres, "Las cláusulas de asistencia mutua y solidaridad tras los atentados de París: la respuesta europea frente al terrorismo internacional”, 57 Revista Española de Derecho Europeo 2016 (forthcoming).

68 Ángel Sánchez Legido, supra n. 49, at 34. 